\title{
Effect of dexamethasone on adipocyte differentiation markers and tumour necrosis factor- $\alpha$ expression in human PAZ6 cells
}

\author{
V.Zilberfarb*, K. Siquier*, A.D. Strosberg, T. Issad \\ Institute Cochin of Molecular Genetics, Paris, France
}

\section{Abstract}

Aims/hypothesis. Adipose tissue-derived tumour necrosis factor- $\alpha$ (TNF- $\alpha$ ) has been implicated in the insulin resistance observed in animal models of obesity. Moreover, TNF- $\alpha$ has inhibitory effects on adipocyte differentiation. Glucocorticoids play important roles in the regulation of insulin sensitivity and adipose tissue distribution. We therefore studied the effect of dexamethasone on TNF- $\alpha$ expression and adipocyte differentiation in human PAZ6 cells.

Methods. The expression of TNF- $\alpha$ and adipocyte differentiation markers was assessed by reversetranscription polymerase chain reaction in PAZ6 cells.

Results. In cells cultured for 15 days in the presence of dexamethasone, adipocyte differentiation marker expression was higher and TNF- $\alpha$ expression was lower than in cells cultured in the absence of dexamethasone. The presence of dexamethasone was necessary during the whole period of differentiation because removal of dexamethasone during the second week resulted in poorly differentiated adipocytes that express higher levels of TNF- $\alpha$.

Dexamethasone also reduced TNF- $\alpha$ expression during early stages of differentiation. The use of a TNF- $\alpha$-neutralising antibody showed, however, that endogenously-produced TNF- $\alpha$ did not play an important part in the control of PAZ6 cell differentiation. During early stages of adipocyte differentiation, dexamethasone induced the expression of the transcription factors PPAR $\gamma$ (peroxisome proliferator activated receptor $\gamma$ ) and $\mathrm{C} / \mathrm{EBP} \alpha(\mathrm{CCAAT} /$ enhancer binding protein $\alpha$ ) while inhibiting the expression of the inhibitor of DNA binding Id2.

Conclusion/interpretation. The effect of dexamethasone on human adipocyte differentiation is not mediated by reduction of TNF- $\alpha$ expression but more likely by regulation of the expression of nuclear factors such as PPAR $\gamma, \mathrm{CEBP} \alpha$ and Id2. [Diabetologia 2001 44: 377-386]

Keywords Adipocyte differentiation, glucocorticoids, dexamethasone, TNF- $\alpha$, gene expression, obesity, insulin resistance.
Received: 14 July 2000 and in revised form: 17 October 2000

Corresponding author: T. Issad, Laboratoire d'Immuno-Pharmacologie Moléculaire, CNRS UPR 415, Institut Cochin de Génétique Moléculaire, 22 rue Méchain, 75014 Paris, France Abbreviations: LPL, lipoprotein lipase; $\operatorname{PPAR} \gamma$, peroxisome proliferator activated receptor $\gamma ; \mathrm{C} / \mathrm{EBP} \alpha, \mathrm{CCAAT} / \mathrm{enhancer}$ binding protein $\alpha$; Id, inhibitor of DNA binding; TNFR, TNF$\alpha$ receptor; ECL, enhanced chemiluminescence.

* V. Zilberfarb and K. Siquier contributed equally to this work.
Tumour necrosis factor- $\alpha$ (TNF- $\alpha)$ is a cytokine that is expressed in different cell types, including adipocytes [1]. In several animal models of obesity, the expression of TNF- $\alpha$ in the adipose tissue is increased [2]. Treatment with a soluble TNF- $\alpha$ receptor-IgG fusion protein, which neutralises TNF- $\alpha$ activity, resulted in increased insulin sensitivity, demonstrating the involvment of abnormal TNF- $\alpha$ production in the insulin resistance associated with obesity [1]. The effects of TNF- $\alpha$ on insulin sensitivity are mediated, at least in part, by inhibition of the tyrosine kinase activity of the insulin receptor [3-5]. It has also been 
shown that TNF- $\alpha$ inhibits the expression of the insulin receptor and IRS1 [6]. Moreover, TNF- $\alpha$ inhibits insulin action by decreasing the expression of the insulin sensitive glucose transporter GLUT-4 [7].

The expression of TNF- $\alpha$ is also increased in adipose tissue of human obese patients and its mRNA levels are correlated with the degree of obesity and hyperinsulinaemia [8, 9]. Because TNF- $\alpha$ is also known to have inhibitory effects on adipocyte differentiation $[10,11]$, it has been proposed that increased TNF- $\alpha$ expression in obesity helps to limit adipose tissue development at the expense of insulin sensitivity [12]. There is, however, no evidence that TNF- $\alpha$ produced by adipocytes regulates adipogenesis in an autocrine or paracrine way. Moreover, the role of adipose tissue-derived TNF- $\alpha$ in insulin resistance in human obesity is still to be firmly established $[13,14]$.

Little is known about the hormonal regulation of TNF- $\alpha$ expression in adipocytes $[15,16]$. Glucocorticoids are known to be increased in different models of obesity and to induce insulin resistance. Adrenalectomy has been shown to reduce fat deposition and to improve insulin sensitivity in animal models of obesity [17]. In humans, an excess of glucocorticoids, commonly observed in patients treated with these steroids or affected by Cushing's syndrome, leads to insulin resistance, modification of adipose tissue distribution and central obesity.

We recently immortalised and characterised the first human adipocyte cell line [18-20]. In the present work, we used these cells (PAZ6 cells) to study the effect of a synthetic glucocorticoid, dexamethasone, on adipocyte differentiation and TNF- $\alpha$ expression.

\section{Materials and methods}

Materials. All materials used in this study have been described previously [18-20], except TNF- $\alpha$ (Chemicon, Temecula, Calif., USA), TNF- $\alpha$ antibody (Endogen, Woburn, Mass., USA), human TNF- $\alpha$ ELISA system (Amersham Pharmacia Biotech, Saclay, France), enhanced chemiluminescence (ECL) kit (Amersham Pharmacia Biotech, France) and protein A Sepharose (Sigma-Aldrich, Saint-Quentin Falavier, France).

Culture of PAZ6 cells. Immortalisation of human PAZ6 cells has been described previously [18]. Briefly, human preadipocytes from infant perirenal adipose tissue were transfected by microinjecting the genes coding for SV40 large and small $t$ antigens under the control of the vimentin promoter. Transfected preadipocytes were amplified and kept frozen in liquid nitrogen. These cells can be thawed and passaged weekly up to 20 passages without loosing their capacity to differentiate into mature adipocytes which accumulate fat droplets and express adipocytes differentiation markers.

Throughout this study, PAZ6 cells have been used as follows: preadipocytes were cultured in DMEM-Ham's F-12 (Gibco Life Sciences, Cergy Pontoise, France, 1:1: vol/vol., designated as F/D medium) supplemented with $8 \%$ FCS reagent (Gibco Life Sciences) and $15 \mathrm{mmol} / \mathrm{l}$ HEPES. Fully differentiated adipocytes were obtained by culturing confluent
PAZ6 preadipocytes (approximately $1.5 \cdot 10^{6}$ cells/well) for 2 weeks in F/D medium supplemented with $5 \%$ FCS, $0.1 \mu \mathrm{mol} / 1$ dexamethasone, $850 \mathrm{nmol} / 1$ insulin, $1 \mathrm{nmol} / \mathrm{l} \mathrm{tri-}$ iodothyronine and $1 \mu \mathrm{mol} / \mathrm{l}$ thiazolidinedione (naphthiazo [20]). This medium was designated as differentiation medium. The differentiation medium was changed every other day. During the first 4 days of differentiation, 3-isobutyl-1-methyl-xanthine was added to the differentiation medium (IBMX, $0.25 \mathrm{mmol} / \mathrm{l})$.

Measurement of intracellular triglyceride content. Adipose conversion was measured by staining intracytoplasmic lipids with Oil red O using a previously published protocol [21].

$R N A$ isolation. Total RNA was extracted from PAZ6 cells at different stages of the differentiation protocol using the TRIzol reagent (Gibco Life Sciences, France). Total RNA (20 $\mu \mathrm{g})$ was digested with $6 \mathrm{U}$ rnase-free DNase I (RQ1 DNase, Promega, Lyon, France) in $40 \mathrm{mmol} / \mathrm{l} \mathrm{TRIS}-\mathrm{HCl}, \mathrm{pH} 7.9,10 \mathrm{mmol} / \mathrm{l} \mathrm{NaCl}$, $6 \mathrm{mmol} / \mathrm{l} \mathrm{MgCl}$ and $2 \mathrm{U} / \mathrm{ml}$ rnase inhibitor (rnaseOUT, Gibco Life Sciences, France). The RNA was then extracted with phenol/chloroform, precipitated with ethanol, dried and resuspended in water. Concentrations of RNA were determined photometrically, and integrity of total RNA was assessed by agarose electrophoresis. The samples were stored at $-80^{\circ} \mathrm{C}$.

$R T$-PCR. Complementary DNA was synthesized at $37^{\circ} \mathrm{C}$ for 30 min from 100 ng DNA-free total RNA using Moloney murine leukaemia virus reverse transcriptase (Superscript II Plus, Gibco Life Sciences) in $20 \mu \mathrm{l}$ reverse transcriptase buffer [50 mmol/1 TRIS-HCL, pH 8.3, $75 \mathrm{mmol} / 1 \mathrm{KCl}, 3 \mathrm{mmol} / 1$ $\mathrm{MgCl}_{2}$ and $10 \mathrm{mmol} / \mathrm{l}$ dithiothreitol (DTT)] containing $0.4 \mathrm{mmol} / \mathrm{l}$ each deoxyribonucleoside triphosphate (dNTP), $4 \mu \mathrm{mol} / \mathrm{l}$ random hexanucleotides (Amersham Pharmacia, Biotech, France) and 2U/ml rnase inhibitor. Controls without reverse transcriptase were done to exclude DNA contamination. Generally, $100 \mathrm{ng}$ of reverse-transcribed RNA were amplified with $1.5 \mathrm{U}$ Taq polymerase (Gibco Life Sciences) in $50 \mu \mathrm{l}$ containing $20 \mathrm{mmol} / \mathrm{l}$ TRIS-HCl, pH $8.0,50 \mathrm{mmol} / \mathrm{l} \mathrm{KCl}$, $1.5 \mathrm{mmol} / 1 \mathrm{MgCl}_{2}, 250 \mu \mathrm{mol} / 1 \mathrm{dNTP}$ and $250 \mu \mathrm{mol} / 1$ of genespecific sense primers and antisense-primers in a temperature cycler (GeneAmp PCR System 9600, Perkin-Elmer Cetus, Courtaboeuf, France). The PCR-products were visualized on $2 \%$ agarose gels by ethidium bromide staining. For all RTPCRs, analysis of mRNA expression was carried out during the exponential phase of the amplification, which was assessed in preliminary experiments for each pair of primers. Briefly, 100 ng of reversed transcribed RNA were used in a PCR reaction where the number of cycles was gradually increased (usually from 20 to 35 cycles). The products of the reaction were visualised on gel by ethidium bromide staining and analysed by densitometric scanning. The exponential phase of the reaction was calculated by plotting on a logarithmic scale the intensity of the signal against the number of amplification cycles. During this phase, when the reaction was done with variable amounts of reverse-transcribed mRNA (from 50 to $200 \mathrm{ng}$ ), the signal obtained was proportional to the amount of cDNA used in the reaction.

Primers for the following cDNAs were designed with the program Oligo4 (National Bioscience, Plymouth, Minn., USA) using the following Genbank entries:

Fatty-acid-binding protein (Acc. number J02874): sense 5'TCCAGTGAAAACTTTGATGATTAT3', 5' annealing position 99; antisense 5'ACGCATTCCACCACCAGTTTATCA3', 5' annealing position 418

Peroxisome proliferator-activated receptor $\gamma(\operatorname{PPAR} \gamma)$ (Acc. number L40904): sense 5'AGACAACAGACAAAT- 
CACCAT3', 5' annealing position 894; antisense 5'CTTCACAGCAAACTCAAACTT3', 5' annealing position 1294

Cyclophilin (Acc. number Y00052): sense 5'AGCACTGGAGAGAAAGGATT3', 5' annealing position 132; antisense 5'GGAGGGAACAAGGAAAACAT3', 5' annealing position 659

Lipoprotein lipase (LPL) (Acc. number M76722): sense 5'GAGATTTCTCTGTATGGCACC3', 5' annealing position 267; antisense 5'CTGCAAATGAGACACTTTCTC3', 5' annealing position 3091

Hormone sensitive lipase (Acc. number L11706): sense 5'GGGGCTGAGTTTGAGCG3', 5' annealing position 1298; antisense 5'GCTCCTCACTGTCCTGTCC3', 5' annealing position 1583

TNF- $\alpha$ (Acc. number X01394): sense 5'CAGAGGGAAGAGTTCCCCAG, 5' annealing position 327; antisense 5'CCTTGGTCTGGTAGGAGACG, 5' annealing position 651

CCAAT enhancer-binding protein (C/EBP) $\alpha$ (Acc. number U34 070): sense 5'GACACGCTGCGGGGCATCT, 5' annealing position 1597; antisense 5'CTGCTCCCCTTCCTTCTCTCA, 5' annealing position 2090

C/EBP $\beta$ (Acc. number X52560): sense 5'AACTTTGGCACTGGGGCACT, 5' annealing position 1337; antisense 5'GGCCCGGCTGACAGTTACAC, 5' annealing position 1614

$\mathrm{C} / \mathrm{EBP} \delta$ (Acc. number S63168): sense, 5'GTGGAGCTGTCGGCTGAGAAC, 5' annealing position 710; antisense 5' GGCCGTCGGGTCTGAGGTATG, 5' annealing position 889

Inhibitor of DNA binding (Id)2 (Acc. number M96843): sense 5'CAGTCCCGTGAGGTCCATTA, 5' annealing position 121; antisense 5'AGGCTGACAATAGTGGGATG, 5' annealing position 372

Id3 (Acc. number X73428): sense 5'GCGGTGTGCTGCCTGTCGGA, 5' annealing position 37; antisense 5' CGGCTGTTGGATGGGAAGGT, 5' annealing position 306

TNF- $\alpha$ Receptor 1 (Acc. number M58286): sense 5'CCTACCCCAGATTGAGAATG, 5' annealing position 771; antisense 5'GCCGCACGAATTCCTTCCAG, 5' annealing position 1315

TNF- $\alpha$ Receptor 2 (Acc. number S63368): sense 5'GCTGGCCGTCGGACTGGAGCTCTG, 5' annealing position 119; antisense 5'GGGCTTGCACACCACGTCTGATGT, 5' annealing position 581

GLUT-4 (Acc. number M20747): sense 5' TCCTGCTGCCCTTCTGTC, 5' annealing position 653; antisense 5'GGCCTACCCCTGCTGTCT, 5' annealing position 961

Leptin (Acc. number U43653): sense 5'GCTGTGCCCATCCAAAAAGT, 5' annealing position 61; antisense 5' ACTGCCAGTGTCTGGTCCAT, 5' annealing position 242

Study of TNF- $\alpha$ secretion by PAZ6 cells. Secretion of TNF- $\alpha$ was first studied in our standard culture conditions by analysing TNF- $\alpha$ concentration in the culture medium using a human TNF- $\alpha$ ELISA system, according to the manufacturer's instructions. Because TNF- $\alpha$ production was too low to be detected under these conditions, a large scale culture experiment was undertaken. We immunoprecipitated TNF- $\alpha$ from the culture medium of $45 \cdot 10^{6}$ confluent PAZ6 cells using $0.9 \mu \mathrm{g} / \mathrm{ml}$ of TNF- $\alpha$ antibody and $0.4 \mathrm{mg} / \mathrm{ml}$ of protein A-Sepharose. Samples were submitted to polyacrylamide gel elecrophoresis and transferred to a nitrocellulose membrane as described previously [19]. Immunobotting was done using TNF- $\alpha$ antibody (dilution 1:625) and the reactive bands were visualized by ECL kit according to the manufacturer's instructions.

\section{Results}

Dexamethasone is necessary for the differentiation of PAZ6 adipocytes. To examine the role of dexamethasone in the differentiation of PAZ6 cells, we cultured confluent PAZ6 preadipocytes according to our standard protocol [20] in the absence or presence of dexamethasone. After 2 weeks of culture, we assessed the expression of the following adipocyte markers by semi-quantitative RT-PCR: fatty-acid-binding protein (aP2), insulin sensitive glucose transporter (GLUT-4), hormone sensitive lipase (HSL), leptin, lipoprotein lipase (LPL) and tumour necrosis factor- $\alpha$ (TNF- $\alpha$ ) (Fig.1). In the absence of dexamethasone, the expression of these markers was barely detectable, with the notable exception of TNF- $\alpha$, which was expressed at higher levels in cells cultured in the absence of dexamethasone. This indicates that dexamethasone is necessary for differentiation of PAZ6 cells and that it negatively regulates the expression of TNF- $\alpha$.

In another set of experiments (Fig. 2), PAZ6 adipocytes were cultured during the first week of differentiation in our standard differentiation cocktail. Dexamethasone was removed from the medium during the second week of differentiation. We observed that the expression of the differentiation markers was markedly decreased when dexamethasone was removed during the second week of differentiation (Fig. 2A). This indicates that dexamethasone must be present during the whole differentiation process to obtain a fully differentiated phenotype. Removal of dexamethasone during the second week of differentiation also resulted in an increase in TNF- $\alpha$ expression.

The influence of dexamethasone on the adipocytic phenotype was also evaluated by staining intracellular triglycerides, which accumulate during adipocyte differentiation (Fig. 2B). We observed that virtually no lipid accumulation could be detected in PAZ6 cells cultured 15 days in the absence of dexamethasone. A substantial accumulation of triglycerides was observed when dexamethasone was present during the first week of differentiation. Lipid accumulation was, however, much higher when dexamethasone was present during the whole differentiation process.

Effect of dexamethasone during the early stages of differentiation in PAZ6 cells. To better understand the role of glucocorticoids in adipocyte differentiation and TNF- $\alpha$ expression, we studied the effect of dexamethasone on genes expressed during the initial stages of adipocyte differentiation.

We cultured confluent PAZ6 cells for 4 days in the standard differentiation medium in absence or presence of increasing doses of dexamethasone. At day 4, gene expression was studied by semi-quantitative RT-PCR (Fig. 3). We observed that dexametha- 


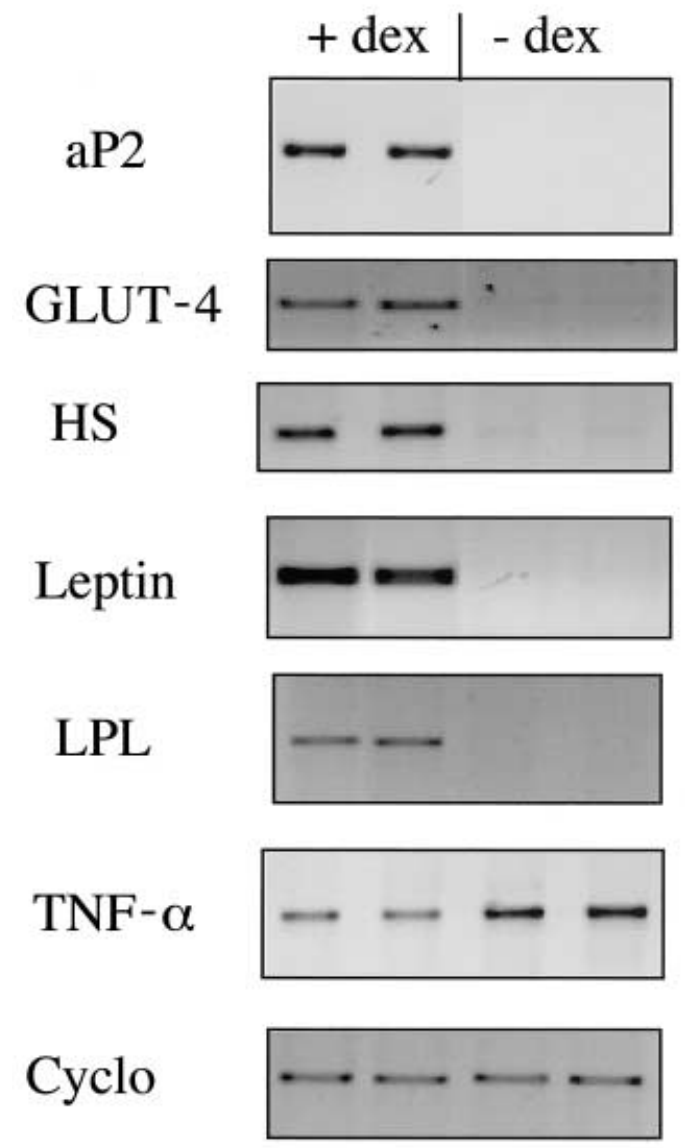

Fig. 1. Effect of dexamethasone (dex) on the expression of adipocyte markers in human PAZ6 cells. After reaching confluence, PAZ6 cells were cultured for 15 days in differentiation medium (see Materials and methods) containing or not 100 $\mathrm{nmol} / \mathrm{l}$ dexamethasone. For each experimental condition, duplicated culture wells were extracted independently and semiquantitative RT-PCR was done on total RNA from each culture well. PCR products were made visible on agarose gels by ethidium bromide staining. As a control, the signals for cyclophilin expression (cyclo) are shown. The results are representative of three independent experiments

sone stimulated the expression of LPL, PPAR $\gamma$ and $\mathrm{C} / \mathrm{EBP} \alpha$ in a dose-dependent manner. Maximal effects for stimulation of the expression of these genes were obtained with $100 \mathrm{nmol} / \mathrm{l}$ dexamethasone. Dexamethasone had no effect on the expression of $\mathrm{C} /$ $\operatorname{EBP} \beta$ and $\mathrm{C} / \operatorname{EBP} \delta$ mRNAs. We also found that dexamethasone dose-dependently inhibited TNF- $\alpha$ expression in PAZ6 cells. In addition, we studied the mRNA expression of Ids proteins, which are dominant-negative regulators of basic helix-loop-helix transcription factors and which have inhibitory effects on the differentiation of various cell types [22]. Dexamethasone dose-dependently reduced the expression of Id 2 in PAZ6 adipocytes but did not affect Id 3 expression.

The effect of dexamethasone was also studied during the earliest stages of the differentiation process (Fig. 4). Total RNAs were isolated from confluent pre-
A
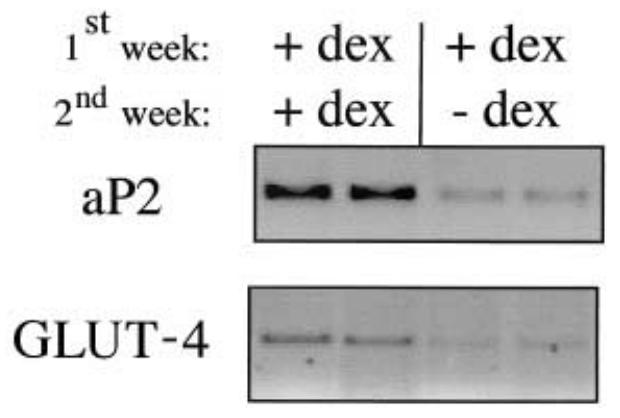

HSL

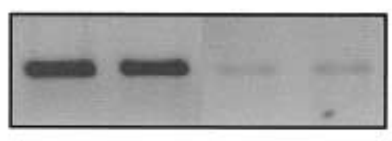

Leptin

LPL
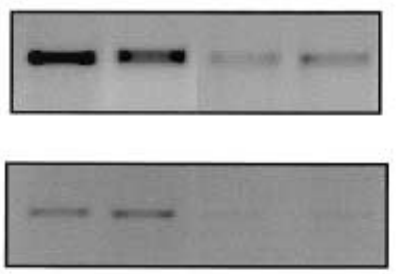

TNF- $\alpha$

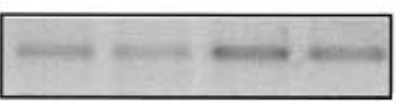

Cyclo

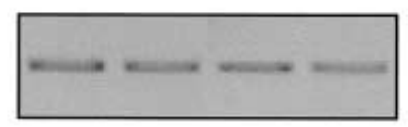

B

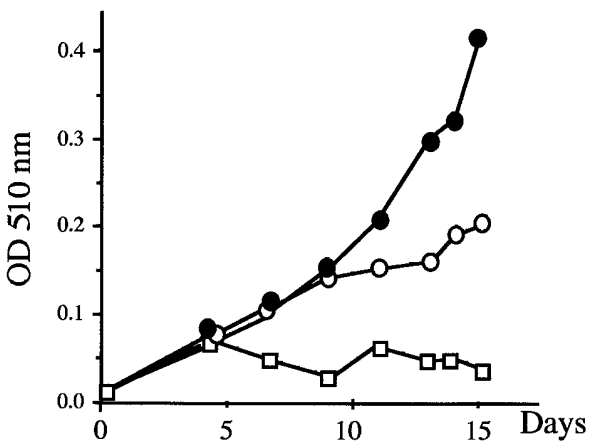

Fig. 2 A, B. Effect of dexamethasone (dex) on the differentiation of human PAZ6 cells. (A) After reaching confluence, PAZ6 cells were cultured for 1 week in differentiation medium with or without $100 \mathrm{nmol} / \mathrm{l}$ dexamethasone. During the second week of differentiation, cells were cultured in the same medium with or without $100 \mathrm{nmol} / 1$ dexamethasone. At day 15, cells were extracted and gene expression was analysed as described in Fig. 1. The results are representative of three independent experiments. (B) Lipid acculmulation in PAZ6 adipocytes was evaluated at different time-points in cells cultured 15 days in the absence of dexamethasone $(\square)$, in cells cultured in the presence of $100 \mathrm{nmol} / \mathrm{l}$ dexamethasone during the first week of differentiation only $(\bigcirc)$ and in cells cultured in the presence of $100 \mathrm{nmol} / \mathrm{l}$ dexamethasone for the 2 weeks of differentiaion 


\section{Dexamethasone (nmol/1)}

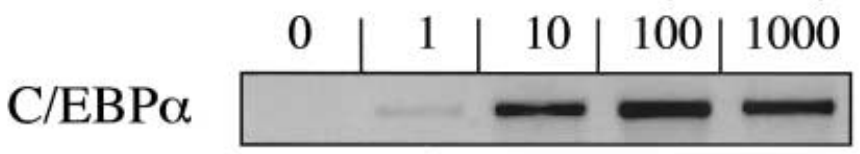

$\mathrm{C} / \mathrm{EBP} \beta$

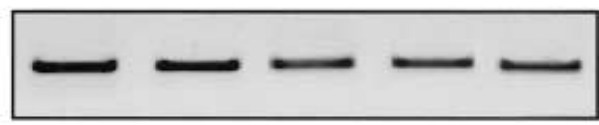

\section{$\mathrm{C} / \mathrm{EBP} \delta$}

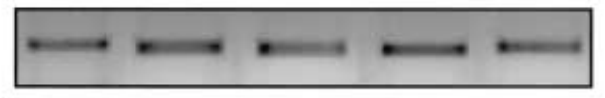

$\operatorname{PPAR} \gamma$

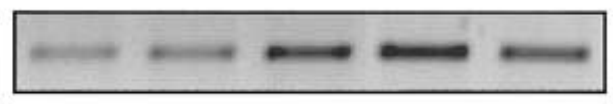

LPL

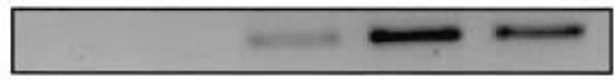

TNF- $\alpha$

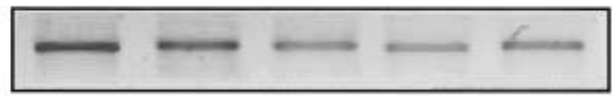

Id 2

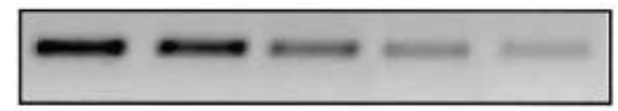

Id3

Cyclo

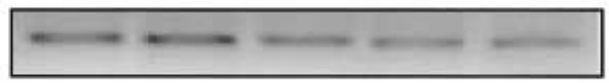

Fig.3. Dose-dependent effect of dexamethasone on gene expression during the early stages of adipocyte differentiation. After reaching confluence, PAZ6 cells were cultured for 4 days in differentiation medium containing increasing concentrations of dexamethasone. At day 4, cells were extracted and gene expression was analysed as described in Fig. 1. The results are representative of two independent experiments

adipocytes (time $=0)$ and after $24 \mathrm{~h}$ of culture in the absence or presence of dexamethasone. The expression of $\mathrm{C} / \mathrm{EBP} \alpha$ mRNA was markedly increased in cells cultured in the presence of dexamethasone but remained very low in cells lacking dexamethasone. No changes in $\mathrm{C} / \mathrm{EBP} \beta$ expression could be detected in these experiments. The expression of $\mathrm{C} / \mathrm{EBP} \delta$ increased after $24 \mathrm{~h}$ of culture but this effect seemed to be independent of the presence of dexamethasone.

The expression of PPAR $\gamma$ and LPL mRNAs was greatly induced after $24 \mathrm{~h}$ of culture in differentiation medium containing dexamethasone, whereas the expression of these genes remained low or undetectable in cells cultured in the absence of dexamethasone.

The expression of TNF- $\alpha$ could be readily detected in confluent PAZ6 preadipocytes. After $24 \mathrm{~h}$ of culture in the differentiation medium containing dexamethasone, TNF- $\alpha$ expression was markedly reduced, whereas its expression remained high in cells
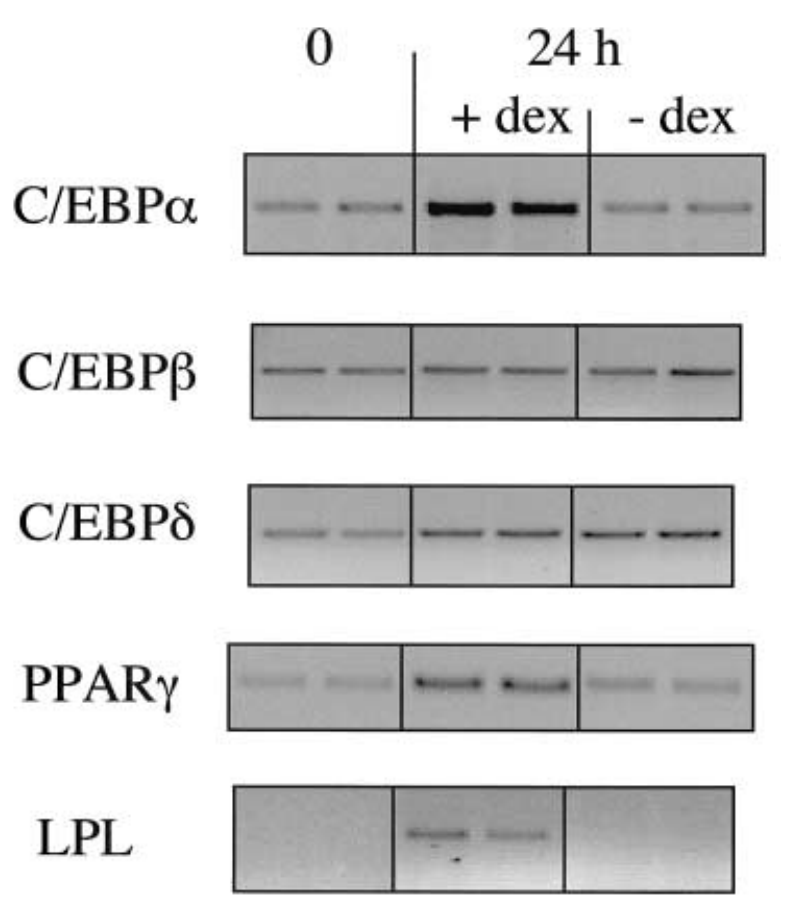

TNF- $\alpha$

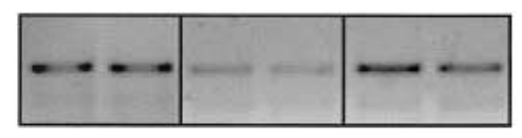

Id 2

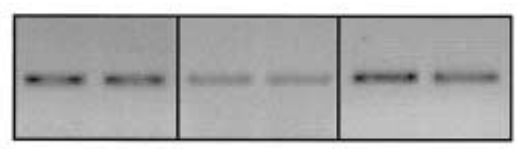

Id 3

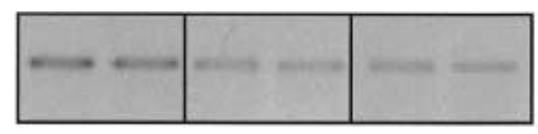

Cyclo

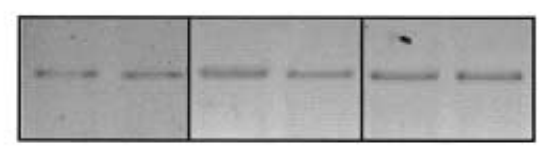

Fig. 4. Effect of dexamethasone (dex) on gene expression during the early stages of PAZ6 differentiation. PAZ6 cells were extracted either at confluence (time 0 ) or after $24 \mathrm{~h}$ of culture in differentiation medium containing or not $100 \mathrm{nmol} / \mathrm{l}$ dexamethasone. Gene expression was analysed as described in Fig. 1. The results are representative of three independent experiments

lacking dexamethasone. A similar pattern of expression was obtained for the inhibitor of DNA binding Id2. Id 3 expression was reduced after $24 \mathrm{~h}$ of differentiation but this effect was independent of the presence of dexamethasone.

PAZ6 cells express functional TNF- $\alpha$ receptors. In rodent and human adipocytes, it has been shown that TNF- $\alpha$ has inhibitory effects on the expression of several differentiation markers $[10,11]$. Thus, TNF- $\alpha$ produced by the adipocyte could act in an autocrine 


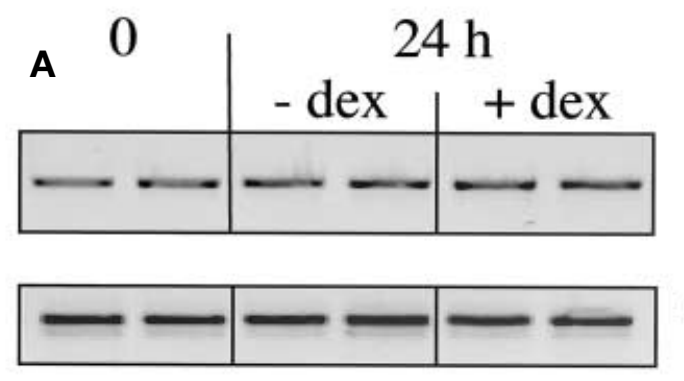

TNFR1

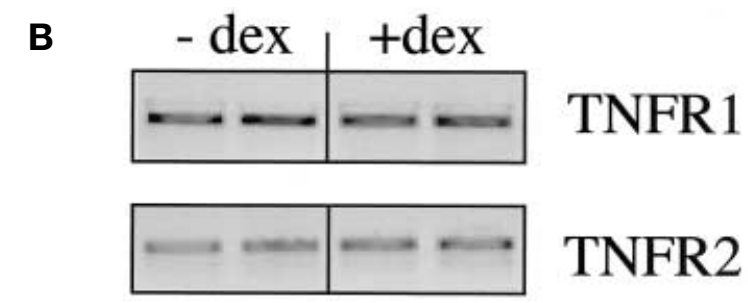

Fig. 5 A, B. Expression of TNF- $\alpha$ receptors in PAZ6 cells. Expression of TNF receptors 1 and 2 was assessed by RT-PCR using total RNA from PAZ6 cells cultured in the absence or presence of dexamethasone (dex). (A) PAZ6 cells were extracted either at confluence (time 0 ) or after $24 \mathrm{~h}$ of culture in differentiation medium with or without $100 \mathrm{nmol} / \mathrm{l}$ dexamethasone. (B) After reaching confluence, PAZ6 cells were cultured for 15 days in differentiation medium with or without $100 \mathrm{nmol} / \mathrm{l}$ dexamethasone. The results are representative of two independent experiments

or paracrine way to control adipogenesis. This raises the possibility that part of the stimulatory effect of dexamethasone on PAZ6 differentiation is mediated by a decreased TNF- $\alpha$ expression. We therefore aimed to determine whether PAZ6 cells express functional TNF- $\alpha$ receptors.

Two types of TNF- $\alpha$ receptors (TNFR1 and TNFR2) could be involved in TNF- $\alpha$ action in adipocytes [23]. Both TNF- $\alpha$ receptor 1 and 2 mRNAs could be detected by RT-PCR in confluent PAZ6 cells (Fig. $5 \mathrm{~A}$ ). The expression of these receptors was not altered by $24 \mathrm{~h}$ incubation in differentiation medium with or without dexamethasone. In Fig. 5 B, confluent PAZ6 cells were cultured for 15 days in differentiation medium with or without dexamethasone. The expression of TNFR1 and TNFR2 was independent of the presence of dexamethasone in the culture medium.

To determine whether TNF- $\alpha$ receptors expressed in PAZ6 adipocytes are functional, fully differentiated cells were incubated with $0.5 \mathrm{nmol} / 1 \mathrm{TNF}-\alpha$ for $24 \mathrm{~h}$. Cells were then harvested and the expression of adipocyte differentiation markers was assessed by semi-quantitative RT-PCR. As described previously in human primary adipocytes [11], TNF- $\alpha$ considerably inhibited the expression of GLUT- 4 and LPL, indicating that $\mathrm{TNF}-\alpha$ receptors expressed in mature PAZ6 cells are capable of mediating inhibitory effects on adipocyte gene expression (Fig.6A). PAZ6 cells
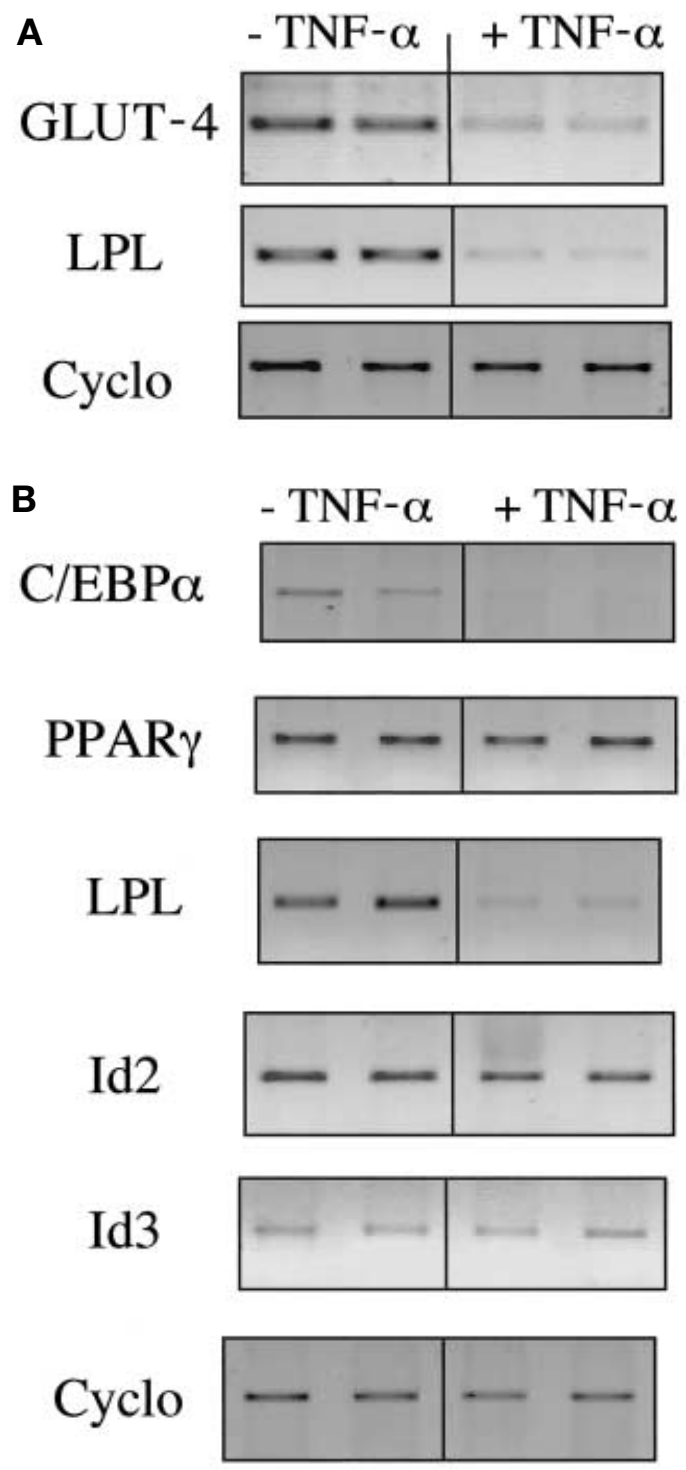

Fig. 6A, B. Effect of TNF- $\alpha$ on gene expression in PAZ6 adipocytes. (A) After reaching confluence, PAZ6 cells were cultured for 15 days in standard differentiation medium. At day 15 , cells were cultured for an additional $24 \mathrm{~h}$ in the same medium with or without $0.5 \mathrm{nmol} / 1 \mathrm{TNF}-\alpha$. (B) After reaching confluence, PAZ6 cells were cultured for $48 \mathrm{~h}$ in standard differentiation medium with or without $0.5 \mathrm{nmol} / 1 \mathrm{TNF}-\alpha$. The results are representative of two independent experiments

were also sensitive to TNF- $\alpha$ during the earliest stages of adipocyte differentiation. At confluence, PAZ6 cells were cultured for $48 \mathrm{~h}$ in the standard differentiation medium containing $0.5 \mathrm{nmol} / \mathrm{l}$ of $\mathrm{TNF}-\alpha$ (Fig. 6B). The expression of LPL and $\mathrm{C} / \mathrm{EBP} \alpha$ was considerably reduced in the presence of TNF- $\alpha$. The $\operatorname{PPAR} \gamma$ and $\mathrm{Id} 2 \mathrm{mRNAs}$ were marginally affected by TNF- $\alpha$ treatment. No effect could be observed on Id3 mRNA expression.

Effect of endogenously produced TNF- $\alpha$ on PAZ6 adipocyte differentiation. We then aimed to determine 
A
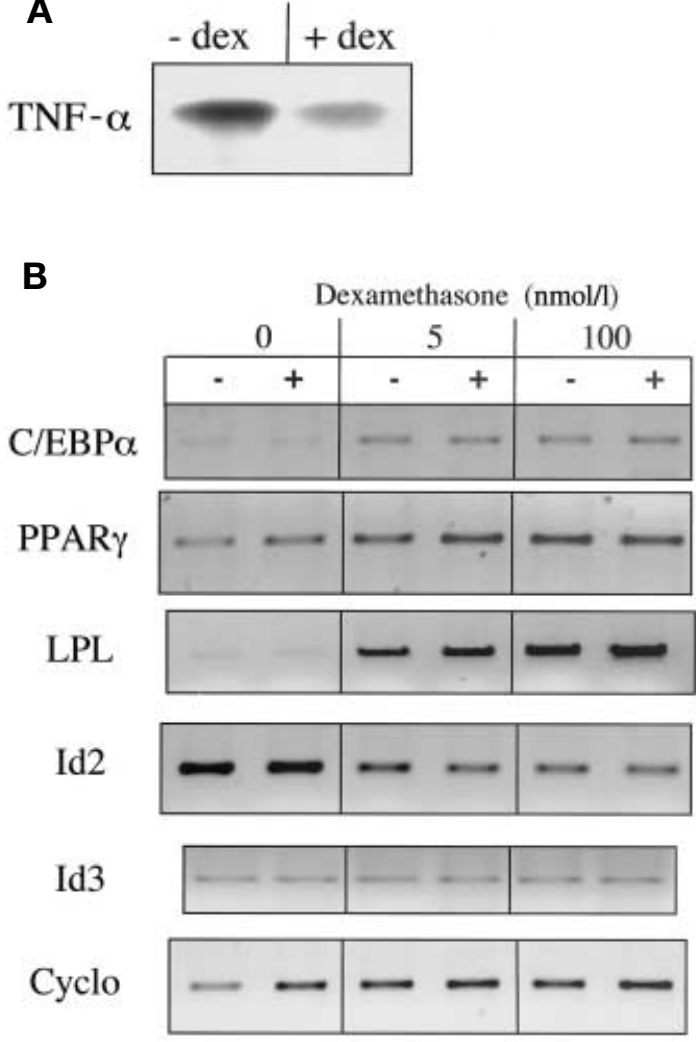

C

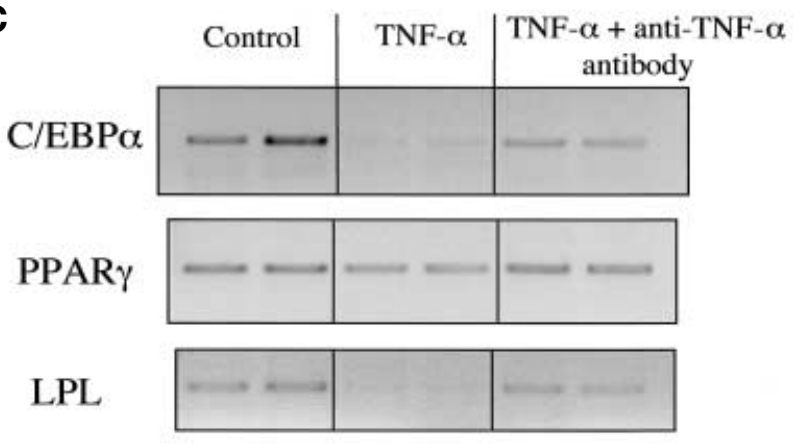

Id 2

Id 3

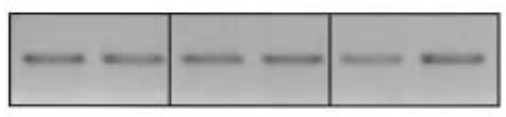

Cyclo

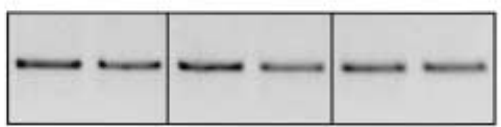

whether TNF- $\alpha$ protein was secreted into the culture medium by PAZ6 cells. In a first set of experiments, PAZ6 preadipocytes were cultured for $48 \mathrm{~h}$ in the absence or presence of dexamethasone using our standard experimental conditions $\left(1.5 \cdot 10^{6}\right.$ confluent PAZ6 cells cultured in $3 \mathrm{ml}$ of medium). The pres-
Fig. 7A, B, C. Effect of endogenously produced TNF- $\alpha$ on gene expression in PAZ6 adipocytes. (A) Confluent PAZ6 preadipocytes were cultured in standard differentiation medium with or without $100 \mathrm{nmol} / \mathrm{l}$ dexamethasone. After $48 \mathrm{~h}$, the culture medium was collected and TNF- $\alpha$ was immunoprecipitated and submitted to western blotting. (B) After reaching confluence, PAZ6 cells were cultured for $48 \mathrm{~h}$ in differentiation medium containing 0,5 or $100 \mathrm{nmol} / \mathrm{l}$ dexamethasone, in the absence or presence of $15 \mu \mathrm{g} / \mathrm{ml}$ of TNF- $\alpha$-neutralising antibody. The results are representative of two independent experiments. (C) After reaching confluence, PAZ6 cells were cultured for $48 \mathrm{~h}$ in standard differentiation medium in the absence or presence of $0.5 \mathrm{nmol} / 1$ recombinant TNF- $\alpha$ and $15 \mu \mathrm{g} / \mathrm{ml}$ of TNF- $\alpha$-neutralising antibody. The results are representative of two independent experiments

ence of TNF- $\alpha$ in the culture medium was assessed by ELISA. We could not detect TNF- $\alpha$ under these conditions, indicating that the TNF- $\alpha$ concentration in the culture medium was below the limit of detection of the assay $(0.3 \mathrm{pmol} / \mathrm{l})$. We therefore carried out a larger scale experiment in which $45 \cdot 10^{6}$ confluent PAZ6 preadipocytes were cultured for $48 \mathrm{~h}$ in the absence or presence of dexamethasone. The amount of TNF- $\alpha$ accumulated in the culture medium was then assessed by immunoprecitpitation followed by western blotting. We found that TNF- $\alpha$ protein was secreted into the culture medium, and its expression considerably reduced in the presence of dexamethasone (Fig. $7 \mathrm{~A}$ ).

To determine whether endogenously produced TNF- $\alpha$ affected adipocyte differentiation, confluent PAZ6 preadipocytes were cultured for $48 \mathrm{~h}$ in the absence or presence of a neutralising anti-TNF- $\alpha$ antibody (Fig. 7 B). We observed that this antibody did not affect the expression of differentiation markers in cells cultured in the absence or presence of 5 or $100 \mathrm{nmol} / \mathrm{l}$ dexamethasone. In contrast, this antibody clearly attenuated the inhibitory effect of exogenous TNF- $\alpha$ on the expression of LPL and CEBP $\alpha$, thus showing its capacity to neutralise TNF- $\alpha$ activity (Fig. 7 C).

This result strongly suggests that endogenously produced TNF- $\alpha$ does not affect PAZ6 adipocyte differentiation and that the effect of dexamethasone on adipocyte differentiation is independent of its inhibitory effects on TNF- $\alpha$ expression.

\section{Discussion}

Glucocorticoids play an important part in determining adipose tissue distribution and function. The effects of glucocorticoids on adipocyte differentiation have been studied in several cell culture models. Although glucocorticoids were generally found to have stimulatory effects on adipocyte differentiation, different results have been obtained depending on the 
cell model studied [24]. For instance, in 3T3 L1 preadipocytes, dexamethasone is required during the early stages of differentiation (generally 2 days), allowing the induction of transcription factors that are necessary for the progression towards the fully differentiated phenotype [25]. After induction of the differentiation process, dexamethasone is dispensable for terminal differentiation of 3T3 L1 adipocytes. In contrast, 3T3 F442A cells can be fully differentiated in the absence of glucocorticoids. Glucocorticoids can even have inhibitory effects on the acquisition of the differentiated phenotype in 3T3 F442A cells, since a glucocorticoid antagonist has been shown to accelerate their differentiation [26]. In primary cells, depending on the species origin and culture conditions, glucocorticoid treatment is either required for differentiation or acts only to accelerate the process [24]. For instance, in primary cultured rat adipocytes, extensive differentiation can occur in the absence of glucocorticoids [27, 28]. In humans, previous work using primary cultured adipose stromal cells showed that cortisol markedly increased the activity of glycerol-3-phosphate dehydrogenase, indicating an important role of glucocorticoids in adipocyte differentiation $[29,30]$. However, no detailed analysis of the effect of glucocorticoids on gene expression has been done in human adipocytes. We showed in our study that dexamethasone is necessary for the expression of most adipocyte differentiation markers in human PAZ6 cells. Moreover, our results clearly show that dexamethasone is required during the whole differentiation process because the presence of dexamethasone during the first week of differentiation was not sufficient to obtain a fully differentiated phenotype.

In $3 \mathrm{~T} 3 \mathrm{~L} 1$ cells, $\mathrm{C} / \mathrm{EBP} \beta$ and $\mathrm{C} / \mathrm{EBP} \delta$ are expressed early in the differentiation programme [31] and seem to play important roles in the initiation of adipogenesis $[25,32,33]$. A stimulatory effect of dexamethasone on the expression of $\mathrm{C} / \mathrm{EBP} \delta$ has been observed in 3T3 L1 cells [31] but has not been described in other cell models [32]. In PAZ6 cells, we could not detect any substantial effect of dexamethasone on the expression of $\mathrm{C} / \mathrm{EBP} \delta$, raising the possibility that the stimulatory effect observed in the 3T3 L1 cells is cell line specific and should not be generalised to other adipose cell models.

We observed that dexamethasone increased the expression of the transcription factors $\operatorname{PPAR} \gamma$ and $\mathrm{C} / \mathrm{EBP} \alpha$ during the initial stages of PAZ6 differentiation. Similar results have been obtained in 3T3 L1 cells [32]. Both $\operatorname{PPAR} \gamma$ and $\mathrm{C} / \mathrm{EBP} \alpha$ have been shown to play a crucial role in adipocyte differentiation. When co-expressed in fibroblastic cell lines, they act synergistically to induce an adipocyte phenotype [34]. Co-expression of these transcription factors in myoblasts results in their transdifferentiation into adipocytes [35]. Thus, the stimulatory effect of dex- amethasone on $\operatorname{PPAR} \gamma$ and $\mathrm{C} / \mathrm{EBP} \alpha$ expression in PAZ6 cells may play an important part in their differentiation into adipocyte. However, even in fibroblasts or myoblasts co-transfected with PPAR $\gamma$ and $\mathrm{C} /$ $\operatorname{EBP} \alpha[34,35]$, dexamethasone was used to obtain optimal differentiation into adipocytes, suggesting there are additional effects of dexamethasone on adipocyte differentiation $[32,36]$.

We observed that dexamethasone markedly reduces the expression of TNF- $\alpha$. An inverse relation between the expression of TNF- $\alpha$ and adipocyte differentiation markers was observed. This raised the possibility that part of the effect of dexamethasone on adipocyte differentiation is mediated by the inhibition of endogenous TNF- $\alpha$ production. Indeed, TNF- $\alpha$ has been shown to inhibit the differentiation of rodent [10] and human adipocytes [11,37] and our experiments showed that PAZ6 adipocyte differentiation is also inhibited by recombinant TNF- $\alpha$. It has been proposed that TNF- $\alpha$ produced by the adipocyte acts in a paracrine or autocrine manner to control adipogenesis $[8,15]$. There is, however, no report demonstrating that endogenously produced TNF- $\alpha$ affect adipocyte differentiation. Our work suggests that regulation of PAZ6 adipocyte differentiation by endogenously produced TNF- $\alpha$ is unlikely. Indeed, a TNF- $\alpha$-neutralising antibody, which clearly inhibits the effect of exogenous TNF- $\alpha$ on gene expression in these cells, did not improve the expression of adipocyte differentiation markers in cells cultured in the absence of dexamethasone.

A dose-dependent inhibition of Id 2 expression was observed in PAZ6 cells cultured with increasing doses of dexamethasone. The Ids are a group of ubiquitous nuclear proteins that possess a helix-loop-helix domain but are missing the basic domain and therefore cannot bind DNA [22]. They act as dominant negative regulators of basic helix-loop-helix transcription factors and have an inhibitory effect on the differentiation of various cell types, including adipocytes. It has been shown that Id 2 and Id 3 expression decreased upon differentiation of cultured 3T3 F442A cells, whereas the expression of these genes remained high in 3T3-C2 fibroblastic cells which do not differentiate into adipocytes [38]. Stable expression of Id3 cDNA in 3T3 F442A clones inhibits their ability to differentiate into mature adipocytes [38]. More recently [39], Id 2 and Id 3 were shown to inhibit the trancriptional activity of the helix-loop-helix transcription factor ADD1/SREBP1c (adipocyte determination and differentiation factor/sterol regulatory element-binding protein 1c), involved in the regulation of gene expression and adipocyte differentiation [40]. In PAZ6 cells, we also observed that Id 2 and Id 3 expression was markedly decreased upon initiation of differentiation. The decrease in Id3 expression was independent of the presence of dexamethasone. In contrast, dexamethasone seemed to be necessary for the inhi- 
bition of Id 2 expression. Thus, inhibition of Id 2 expression could be part of the mechanism by which glucocorticoids stimulate adipocyte differentiation.

Consideration has to be given to the fact that immortalised PAZ6 cells have abnormal properties compared with primary adipocytes. We have, however, previously shown that several important features described in other adipocytes models are also observed in PAZ6 cells. For instance, in agreement with results obtained using rodent cell lines $[41,42]$ and human primary adipocytes [43], PPAR $\gamma$ ligands have potent stimulatory effects on triglyceride accumulation and expression of adipocyte differentiation markers in PAZ6 cells [20]. Moreover, the stimulatory effect of $\operatorname{PPAR} \gamma$ ligands on uncoupling protein 2 expression, which was first described in rodent adipocytes [44, 45], was also observed in human PAZ6 cells [20] and more recently in primary human adipocytes [46]. Finally, in the present study, we show that the inhibitory effect of exogenous TNF- $\alpha$ on adipocyte differentiation, previously described in rodent [10] and human adipose cells [11,37], is also observed in human PAZ6 adipocytes. Altogether, these observations strongly suggest that immortalised PAZ6 cells constitute an appropriate human model for the study of the regulation of gene expression and adipocyte differentiation.

We have shown that, in PAZ6 human adipocytes, dexamethasone is necessary during the whole differentiation period to obtain a fully differentiated phenotype. Dexamethasone has an inhibitory effect on TNF- $\alpha$ mRNA expression. Although PAZ6 cells are sensitive to exogenous TNF- $\alpha$, the use of a TNF- $\alpha$ neutralising antibody indicates that endogenously produced TNF- $\alpha$ does not significantly affect adipocyte differentiation. This suggests that the effect of dexamethasone on adipocyte differentiation is unlikely to be mediated by inhibition of TNF- $\alpha$ expression. This work also showed that the expression of the inhibitor of DNA binding Id2 is markedly reduced by dexamethasone.

Acknowledgements. We are very grateful to Dr. J. Duhault from the International Research Institute, Servier (Institut de Recherche International Servier) (IRIS, Courbevoie, France) for kindly providing us with naphthiazo. This work was supported by the French Funds (Foundation de France), the National Centre Scientific Research (Centre National de Recherche Scientifique), and the University Paris VII. We thank Drs L. Brydon, P-O. Couraud and R. Jockers for their critical reading of the manuscript.

\section{References}

1. Hotamisligil GS, Shargill NS, Spiegelman BM (1993) Adipose expression of tumour necrosis factor-alpha: direct role in obesity-linked insulin resistance. Science 259: 87-91

2. Hotamisligil GS, Spiegelman BM (1994) Tumour necrosis factor alpha: a key component of the obesity-diabetes link. Diabetes 43: 1271-1278
3. Hotamisligil GS, Budavari A, Murray D, Spiegelman BM (1994) Reduced tyrosine kinase activity of the insulin receptor in obesity-diabetes. Central role of tumour necrosis factor-alpha. J Clin Invest 94: 1543-1549

4. Hotamisligil GS, Murray DL, Choy LN, Spiegelman BM (1994) Tumour necrosis factor alpha inhibits signaling from the insulin receptor. Proc Natl Acad Sci U S A 91: 4854-4858

5. Hotamisligil GS, Peraldi P, Budavari A, Ellis R, White MF, Spiegelman BM (1996) IRS-1-mediated inhibition of insulin receptor tyrosine kinase activity in TNF-alpha- and obesity-induced insulin resistance. Science 271: 665-668

6. Stephens JM, Lee J, Pilch PF (1997) Tumour necrosis factor-alpha-induced insulin resistance in 3T3-L1 adipocytes is accompanied by a loss of insulin receptor substrate- 1 and GLUT4 expression without a loss of insulin receptormediated signal transduction. J Biol Chem 272: 971-976

7. Stephens JM, Pekala PH (1991) Transcriptional repression of the GLUT4 and C/EBP genes in 3T3-L1 adipocytes by tumour necrosis factor-alpha. J Biol Chem 266: 21839-21845

8. Kern PA, Saghizadeh M, Ong JM, Bosch RJ, Deem R, Simsolo RB (1995) The expression of tumour necrosis factor in human adipose tissue. Regulation by obesity, weight loss, and relation to lipoprotein lipase. J Clin Invest 95: 2111-2119

9. Hotamisligil GS, Arner P, Caro JF, Atkinson RL, Spiegelman BM (1995) Increased adipose tissue expression of tumour necrosis factor-alpha in human obesity and insulin resistance. J Clin Invest 95: 2409-2415

10. Stephens JM, Pekala PH (1992) Transcriptional repression of the C/EBP-alpha and GLUT4 genes in 3T3-L1 adipocytes by tumour necrosis factor-alpha. Regulations is coordinate and independent of protein synthesis. J Biol Chem 267: 13580-13584

11. Hauner H, Petruschke T, Russ M, Rohrig K, Eckel J (1995) Effects of tumour necrosis factor alpha (TNF alpha) on glucose transport and lipid metabolism of newly-differentiated human fat cells in cell culture. Diabetologia 38: 764-771

12. Spiegelman BM, Hotamisligil GS (1993) Through thick and thin: wasting, obesity, and TNF alpha. Cell 73: 625-627

13. Saghizadeh M, Ong JM, Garvey WT, Henry RR, Kern PA (1996) The expression of TNF alpha by human muscle. Relation to insulin resistance. J Clin Invest 97: 1111-1116

14. Ofei F, Hurel S, Newkirk J, Sopwith M, Taylor R (1996) Effects of an engineered human anti-TNF-alpha antibody (CDP571) on insulin sensitivity and glycemic control in patients with NIDDM. Diabetes 45: 881-885

15. Hube F, Lee YM, Rohrig K, Hauner H (1999) The phosphodiesterase inhibitor IBMX suppresses TNF-alpha expression in human adipocyte precursor cells: a possible explanation for its adipogenic effect. Horm Metab Res 31: 359-362

16. Sewter CP, Digby JE, Blows F, Prins J, O'Rahilly S (1999) Regulation of tumour necrosis factor-alpha release from human adipose tissue in vitro. J Endocrinol 163: 33-38

17. Bray GA, York DA (1979) Hypothalamic and genetic obesity in experimental animals: an autonomic and endocrine hypothesis. Physiol Rev 59: 719-809

18. Zilberfarb V, Pietri-Rouxel F, Jockers R et al. (1997) Human immortalized brown adipocytes express functional beta3-adrenoceptor coupled to lipolysis. J Cell Sci 110: 801-807

19. Jockers R, Issad T, Zilberfarb V, de Coppet P, Marullo S, Strosberg AD (1998) Desensitization of the beta-adrenergic response in human brown adipocytes. Endocrinology 139: 2676-2684 
20. Strobel A, Siquier K, Zilberfarb V, Strosberg AD, Issad T (1999) Effect of thiazolidinediones on expression of UCP2 and adipocyte markers in human PAZ6 adipocytes. Diabetologia 42: 527-533

21. Ramirez-Zacarias JL, Castro-Munozledo F, Kuri-Harcuch W (1992) Quantitation of adipose conversion and triglycerides by staining intracytoplasmic lipids with Oil red O. Histochemistry 97: 493-497

22. Norton JD, Deed RW, Craggs G, Sablitzky F (1998) Id helix-loop-helix proteins in cell growth and differentiation. Trends Cell Biol 8: 58-65

23. Liu LS, Spelleken M, Rohrig K, Hauner H, Eckel J (1998) Tumour necrosis factor-alpha acutely inhibits insulin signaling in human adipocytes: implication of the p80 tumour necrosis factor receptor. Diabetes 47: 515-522

24. Gregoire FM, Smas CM, Sul HS (1998) Understanding adipocyte differentiation. Physiol Rev 78: 783-809

25. Yeh WC, Cao Z, Classon M, McKnight SL (1995) Cascade regulation of terminal adipocyte differentiation by three members of the $\mathrm{C} / \mathrm{EBP}$ family of leucine zipper proteins. Genes Dev 9: 168-181

26. Feve B, Antras J, Lasnier F, Hilliou F, Pairault J (1989) The antiglucocorticoid RU38486 is a potent accelerator of adipose conversion of 3T3-F442A cells. Mol Cell Endocrinol 67: 17-27

27. Deslex S, Negrel R, Ailhaud G (1987) Development of a chemically defined serum-free medium for differentiation of rat adipose precursor cells. Exp Cell Res 168: 15-30

28. Gregoire F, Todoroff G, Hauser N, Remacle C (1990) The stroma-vascular fraction of rat inguinal and epididymal adipose tissue and the adipoconversion of fat cell precursors in primary culture. Biol Cell 69: 215-222

29. Hauner H, Schmid P, Pfeiffer EF (1987) Glucocorticoids and insulin promote the differentiation of human adipocyte precursor cells into fat cells. J Clin Endocrinol Metab 64: 832-835

30. Hauner H, Entenmann G, Wabitsch M et al. (1989) Promoting effect of glucocorticoids on the differentiation of human adipocyte precursor cells cultured in a chemically defined medium. J Clin Invest 84: 1663-1670

31. Cao Z, Umek RM, McKnight SL (1991) Regulated expression of three $\mathrm{C} / \mathrm{EBP}$ isoforms during adipose conversion of 3T3-L1 cells. Genes Dev 5: 1538-1552

32. Wu Z, Bucher NL, Farmer SR (1996) Induction of peroxisome proliferator-activated receptor gamma during the conversion of 3T3 fibroblasts into adipocytes is mediated by $\mathrm{C} / \mathrm{EBPbeta}, \mathrm{C} / \mathrm{EBPdelta}$, and glucocorticoids. Mol Cell Biol 16: 4128-4136

33. Darlington GJ, Ross SE, MacDougald OA (1998) The role of C/EBP genes in adipocyte differentiation. J Biol Chem 273: 30057-30060
34. Tontonoz P, Hu E, Spiegelman BM (1994) Stimulation of adipogenesis in fibroblasts by PPAR gamma 2, a lipid-activated transcription factor Cell 79: 1147-1156

35. Hu E, Tontonoz P, Spiegelman BM (1995) Transdifferentiation of myoblasts by the adipogenic transcription factors PPAR gamma and C/EBP alpha. Proc Natl Acad Sci U S A 92: 9856-9860

36. Smas CM, Chen L, Zhao L, Latasa MJ, Sul HS (1999) Transcriptional repression of pref-1 by glucocorticoids promotes 3T3-L1 adipocyte differentiation. J Biol Chem 274: 12632-12641

37. Petruschke T, Hauner H (1993) Tumour necrosis factor-alpha prevents the differentiation of human adipocyte precursor cells and causes delipidation of newly developed fat cells. J Clin Endocrinol Metab 76: 742-747

38. Moldes M, Lasnier F, Feve B, Pairault J, Djian P (1997) Id3 prevents differentiation of preadipose cells. Mol Cell Biol 17: 1796-1804

39. Moldes M, Boizard M, Liepvre XL, Feve B, Dugail I, Pairault J (1999) Functional antagonism between inhibitor of DNA binding (Id) and adipocyte determination and differentiation factor $1 /$ sterol regulatory element-binding protein-1c (ADD1/SREBP-1c) trans-factors for the regulation of fatty acid synthase promoter in adipocytes. Biochem J 344 Pt 3: 873-880

40. Kim JB, Spiegelman BM (1996) ADD1/SREBP1 promotes adipocyte differentiation and gene expression linked to fatty acid metabolism. Genes Dev 10: 1096-1107

41. Kletzien RF, Clarke SD, Ulrich RG (1992) Enhancement of adipocyte differentiation by an insulin-sensitizing agent. Mol Pharmacol 41: 393-398

42. Ibrahimi A, Teboul L, Gaillard D, et al. (1994) Evidence for a common mechanism of action for fatty acids and thiazolidinedione antidiabetic agents on gene expression in preadipose cells. Mol Pharmacol 46: 1070-1076

43. Adams M, Montague CT, Prins JB, et al. (1997) Activators of peroxisome proliferator-activated receptor gamma have depot-specific effects on human preadipocyte differentiation. J Clin Invest 100: 3149-3153

44. Aubert J, Champigny O, Saint-Marc P, et al. (1997) Upregulation of UCP-2 gene expression by PPAR agonists in preadipose and adipose cells. Biochem Biophys Res Commun 238: 606-611

45. Camirand A, Marie V, Rabelo R, Silva JE (1998) Thiazolidinediones stimulate uncoupling protein-2 expression in cell lines representing white and brown adipose tissues and skeletal muscle. Endocrinology 139: 428-431

46. Digby JE, Crowley VE, Sewter CP, Whitehead JP, Prins JB, O'Rahilly S (2000) Depot-related and thiazolidinedioneresponsive expression of uncoupling protein 2 (UCP2) in human adipocytes. Int $\mathrm{J}$ Obes Relat Metab Disord 24: 585-592 